\title{
A DÉL-DUNÁNTÚL GAZDASÁGSZERKEZETE ÉS IPARA
}

(The Economic Structure and Industry of Southern Transdanubia)

\section{HRUBI LÁSZLÓ}

A területi gazdaság szerkezetének megítélése, értékelése - különösen a jelenlegi körülmények között - meglehetôsen viszonylagos. Nincsenek általános, tértôl és idôtổl független etalonok, és még a makrogazdaság szerkezete sem jelent feltétlenül követendõ modellt. A regionális gazdaság és a regionális piac fokozatos kibontakozásával, épúlésével ugyanis a területi gazdasági fejlôdés és szerkezet egyre inkább a belsố erôk mozgósítására támaszkodik, és a tartós fejlödōképesség megteremtése (egyfajta regionális fejlỏdési egyensúly kialakulása és fenntartása) éppen a helyi adottságok, feltételek és lehetôségek bázisán, azokat maximálisan (vagy ezt közelítôen optimálisan) hasznosítva és számításba véve képzelhetô el. Mivel a területi adottságok és körülmények különbözôek, az ennek alapján álló gazdaság és annak szerkezete is differenciált. Attól, hogy egy struktúra különbözik a viszonyítás alapjától, még nem következik, hogy jobb, vagy rosszabb is egyben.

A szerkezet megítélésekor vannak azután olyan, szinte kritériummá merevedett szemléletmódok, amelyeket feltétlenül kerülni kell.

Az elsõ ilyen az úgynevezett iparosítási megközelítés, amely egy területi egység fejlettségét, szerkezetét az ipar szerepével, részarányával kapcsolja össze. Általánosabb formában ebben egyfelöl egy korábbi (területi) növekedési modell, másfelốl a meghaladott társadalmi-gazdasági rendszer örökségeként szinte dogmává kövesült gazdaságpolitikai mítosz, a termelô és nem termelô ágak szétválasztásán belül a termelố tevékenységek prioritását (túl)hangsúlyozó gazdaságpolitikai filozófia összegzôdik. A területi gazdasági fejlôdésnek és a szerkezetátalakításnak nem egyedüli, és - egyre inkább - nem feltétlenül az elsõdleges útja az iparfejlôdés, fổleg, ha az a programokban, koncepciókban vidéki iparfejlesztés, falusi iparfejlesztés, ipari munkahelyek létesítése, a mezôgazdasági foglalkoztatás iparival történổ kiváltása és egyéb szlogenek formájában jelenik meg. A regionális fejlôdés részbeni agrárkaraktere - megfelelỗ adottságok és feltételek esetén - tartósan fennmaradhat, sốt a gazdaságilag elmaradott, rurális övezetekben a továbblétezésük éppenséggel nem gazdaságszerkezeti kérdés, hanem szükségszerûség.

Az iparhoz kötôdổ regionális fejlesztési megközelités egyik származéka az úgynevezett húzóágazati koncepció. Ez különösen a 90-es évek fordulóján vagy azt megelõzõen volt népszerũ a területi dokumentumokban, de a hatása nem múlt még el.

A húzóágazat eredeti értelmezésben olyan gazdasági tevékenység, amely magas, (innovativ) technológiai színvonala, a végtermék fejlettsége, összetettsége és szinte korlát- 
lan piaci lehetôsége, jövedelmezôsége (sốt az extraprofit elérhetổsége), kiterjedt (termelési, beszállítási, fejlesztési-kutatási, értékesítési stb.) kooperációs szükséglete és az ezt megalapozó, kölcsönös gazdasági érdekeltségen nyugvó tagolt munkamegosztási rendszere miatt képes folyamatos növekedési-fejlôdési impulzusokat továbbítani a vele szoros kapcsolatban álló területi-gazdasági térnek (vállalatok, szervezetek alkotta területi gazdasági rendszernek), ösztönözni s egyszersmind összefogni egy térség gazdaságának növekedését (a térség ebben az összefüggésben nyilván eléggé kiterjedt is lehet). Mivel - a növekedési pólus és centrum koncepcióhoz is kötõdõen - a felsoroltakhoz megfeleló tớkeellátottság és -koncentráció is társul, így a koncepciónak jószerével egyetlen feltétele sem állt (és áll) rendelkezésre sem nálunk, sem Kelet-Európában.

Ennek a megközelítésnek van azonban egy szelídített változata, és vélhetôen emiatt (volt) oly népszerũ. Ez pedig az, hogy a húzóágazat egy - a környezetéhez képest, itt és most - relatíve fejlett tevékenység, amely az általa támasztott követelmények és azok teljesítése esetén, egy tartósan biztos piac ígérete által, alkalmazkodásra készteti a vele munkamegosztási kapcsolatban álló gazdasági egységeket is. Ebben az értelmezésben azonban azért problematikus a nézôpont, mert a területi gazdasági fejlôdés és a szerkezetátalakítás (köz)gazdasági kategória. Itt pedig arról van szó, hogy a területi gazdasági potenciált alkotó szervezetek egy jelentôs hányada nem érintkezik közvetlenül a piaccal, annak követelményeit számára valaminek kívülrôl közvetítenie kell. Az, hogy nincs közvetlen piaci kapcsolata, jelentheti azt, hogy nincs elégséges piaci ismerete: ez voltaképpen - fổként kisméretú szervezetek esetében - nem természetellenes állapot, ám a húzóágazat ekkor üzleti-pénzügyi-tanácsadó infrastrukturát helyettesít. Ha pedig egy szervezetnek azért nincs közvetlen piaci kapcsolata, mert nem képes azt megteremteni és fenntartani, akkor a húzóágazat az adaptáció egyfajta tréning-eszköze, és az ilyen szerepkörú szervezetek helyettesítôje, vagy adott esetben az alkalmazkodni önállóan képtelen szervezetek átmeneti életben tartója is. Ez a fajta kapcsolat más összefüggésben gyakorta megjelenik a nagy szervezetek lebontásakor is: egyes funkciók önálló szervezettel leválnak, de ,,piacuk” kizárólag az anyavállalat marad. A folyamat így egy ,,kvázi-szerkezetátalakulás” csupán. Valóssá akkor válhat, ha az elbocsátott szervezet képes lesz a ,,külsô piacon" is helytállni, abba beilleszkedni. A szervezeti karcsúsításnak ez a módja egyébként a fejlettebb európai országokban is elôfordul, és a tercierizációnak ez a virtuális alfolyamata az ottani szakmai körök érdeklődését is felkeltette. Céljuk, hogy elkülönítsék azt a valós fejlổési folyamattól.

A területi gazdasági szerkezet megítéléséhez ha nincsenek is egységes, teljes etalonok, azért néhány tendencia a szerkezetváltás kapcsán zsinórmértékül szolgálhat.

Ilyen általában tapasztalható irányzat például:

- a foglalkoztatási szerkezet módosulása a szekunder, és fổleg a tercier szféra irányában;

- az iparon belül a feldolgozó jellegũ ágazatok térnyerése;

- az iparon belül a városi települések privilégiumának oldódása;

- az új szervezetek térbeli terjedésének elôrehaladása. 


\section{A Dél-Dunántúl gazdasági szerkezete}

A Dél-Dunántúl gazdasága a maga egészében különösebb szerepet nemigen kapott a korábbi idôszak központilag vezérelt gazdaságfejlesztésében.

„Átlagos pozíciója”, a ,,félárnyék"-helyzet ma is, korábban is jellemzô volt. A térség egy-egy ágazata vagy kisebb körzete fejlesztési területként azért elôfordult, ezek azonban értelemszerũen elsõrendũen nem a regionális, hanem az ágazati (vagy makrogazdasági) szempontokat és érdekeket követték. A fejlesztések nem elhanyagolható területi hatása csak másodlagos szerepet játszott. Ilyenek voltak Baranyában a kitermeló-iparhoz kötódó fejlôdési ,,aranykor"; Somogyban a Balaton-part fejlesztése, majd egy második lépcsõben a fejlesztés révén elöállt környezeti romlás miatti rehabilitáció törekvései; Tolnában a paksi atomerổmũ és ellenpontként Szekszárd fejlesztése, iparosítása; Zalában pedig elôbb a szénhidrogén-kitermelés programja, utóbb egy megkésett feldolgozóipari fejlesztés, majd az ugyancsak a Balaton-parthoz kötôdô fejlesztési intézkedések, hogy csak néhány jellegzetes vonulatot említsünk.

A régió több körzete - némiképp utalva a gazdasági fejlôdés helyzetére - gyakorta szerepelt a különbözô területi egyenlötlenség-mérséklési programokban is, így Baranyában a Dráva-mellék (Ormánság) és a Zselic-Hegyhát, Tolna megye déli (a baranyai körzettel érintkezô) és nyugati (a somogyi elmaradott térséggel érintkezõ) határvidéke, Somogyban Tab körzete, Zala megyében pedig elsôsorban a göcseji rész, kiegészülve más aprófalvas mikrokörzetekkel. A több mint két évtizedes próbálkozások azonban jórészt hatástalanok voltak, a gazdaság - és azon belül a leginkább forszírozott ipar - fejlôdôképességét érdemben és tartósan alig-alig szolgálták.

Ez a sem nem kiemelt, sem nem teljesen elhanyagolt pozíció a 90-es évek fordulóját követôen részben jó, részben kevésbé kedvezõ következményekkel járt. Kétségtelen, hogy a kiemelt (ipari) fejlesztések tartós stratégiájának hiánya megóvta a térséget a modellváltás nyomán jelentkezó látványos összeomlásoktól. Ebben a régióban inkább lokalizálható körzeti krízishelyzetek jöttek létre (vagy csak tovább éltek a gazdaságilag elmaradott térségekben). Kétségtelenül kedvezôtlen örökség viszont, hogy a régió egy jelentốs része infrastrukturálisan fejletlen maradt, gazdasága mind fizikai, mind pedig közgazdasági értelemben kevéssé kötôdött közvetlen módon az európai és a világpiachoz (legfeljebb közvetítôkk révén). Mivel pedig sem korábban, sem pedig a rendszerváltás elsố éveiben a régió gazdasága, és ezen belül az ipara gazdaságpolitikai értelemben - néhány egységtôl eltekintve - fontosabb szerepet nem játszott, valamint közvetlen piaci befolyásoltsága is mérsékeltebb volt, az új körülményekhez való alkalmazkodása, átalakulása is kissé megkésve megy végbe. Talán a kényszerek sem hatottak rá olyan erôvel, mint másutt, holott az örökölt, többségében volt fióktelephely-vállalatok önálló és piacképes vállalkozássá szervezése rendkivül nehéz feladat (sok esetben reménytelen is). A tapasztalható önfelélō-halogató, a privatizációra passziv módon váró magatartásnak viszont a kumulálódott csekélyebb vagyon szab gátat. 
Az aktív keresốk gazdasági ágak szerinti megoszlásában 1980 és 1990 között a régióban mérsékelt elmozdulások voltak. Ezek a változások összességükben nem módosították azt az alapvetô szerkezeti jellegzetességet, hogy a régió - Baranya megyét kivéve - sokkal inkább agrárjellegũ térség, mint az ország egésze (1. táblázat). A mezõgazdaságban és erdỏgazdálkodásban foglalkoztatottak aránya mind a négy megyében csökkent ugyan a 80-as évtizedben, de még így is hangsúlyos maradt az ágazat szerepe. Ez a tény, valamint az, hogy Somogy és Zala megyében volt a legradikálisabb a fogyatkozás, arra utal, hogy kevésbé a regionális adottságokhoz való illeszkedés, hanem sokkal inkább az elmaradt fejlốdés okozta kényszer rajzolta az agrárkarakter képét. A régión belül csak Tolna adottságai indokolják ezt a szintet, a legkevésbé pedig a többségében gyenge természeti feltételũ Somogy és Zala (ezért aztán itt a legnagyobb a leépülés). (A továbbiakban a mezõgazdaság szerepe statisztikailag követhetetlenné is válik: a 90-es években a tulajdonosi szerkezet és a szervezet átalakításával látszólag az európai szint közelébe esik - $10 \%$ alá - a mezõgazdasági aktív keresõk aránya, de nyilvánvalóan nem csökken a mezõgazdaság szerepe a népesség életében. Nem valószínũ, hogy az ,,eltũnt" tömeg más ágazatokba konvertálódik, inkább inaktívvá, munkanélkülivé vagy kistermelôvé válik, amiáltal mindhárom esetben megmarad az agrár jelleg.)

A gazdasági szerkezet ezen általános regionális jellege a gazdasági szervezetek ágazati megoszlásában is kimutatható (2. táblázat). 1991 végén a régió népességének $12-13 \%$ os országos arányával szemben a jogi személyiségũ gazdasági szervezeteknek csak a 9,6\% -a található itt, viszont a mezôgazdasági és erdôgazdálkodási egységeknek a 15,9\% -a (kiugró még a vízgazdálkodási szervezetek magas részesedési mutatója: a szervezeti formákra vonatkozó statisztikák szerint a régióban viszonylag sok és kicsi társulat mũködik, a vízgazdálkodás jellemzõen lokális szervezetũ és nem regionális).

A szerkezeti átalakulás egyik jellemzõ európai trendje a tercierizáció, a harmadik szektorban foglalkoztatottak részarányának növekedése. Magyarországon ez a folyamat - mivel szorosan összefügg a gazdaság, a piac fejlettségével, a fogyasztással, a jövedelmi helyzettel stb. - némileg hátrébb tart, mint az Európai Unió tagállamaiban. Nálunk 1990-ben a GDP 56\%-át adta a szolgáltatási szektor (12\%-ot a mezõgazdaság, $32 \%$-ot pedig az ipar), amely hozzávetõlegesen azonos a fejletlenebb államok, így Görögország, Spanyolország és Portugália rátájával, és némileg meghaladja az ír mutatót (1. ábra). A foglalkoztatottak arányát illetôen már nagyobb a lemaradás (2. ábra).

A magyar átlagértékhez képest a régió négy megyéje - a foglalkoztatottságot tekintve - 1990-ben általában gyengébb mutatókkal rendelkezett, Somogy megyét kivéve (3. táblázat). 


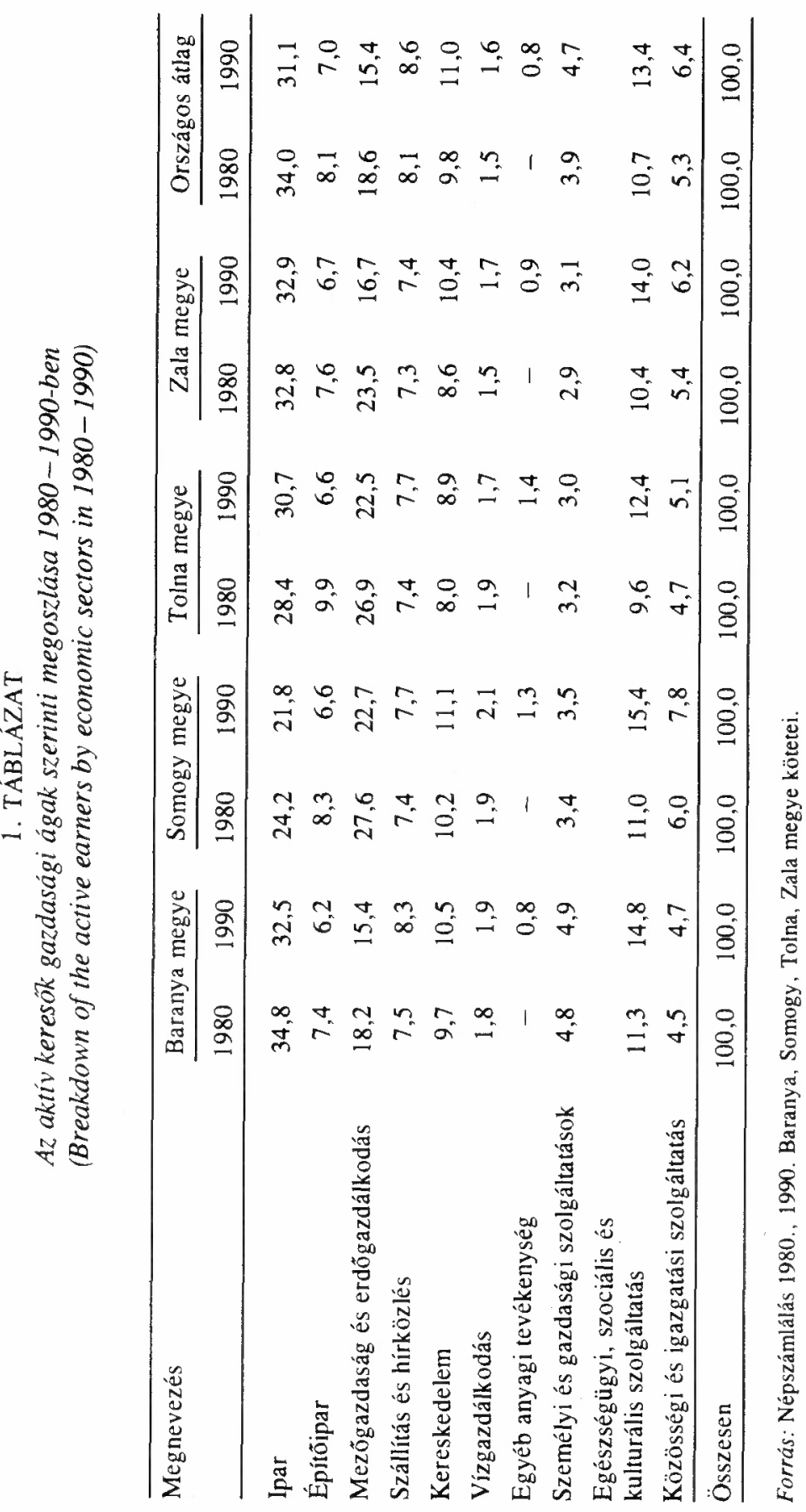




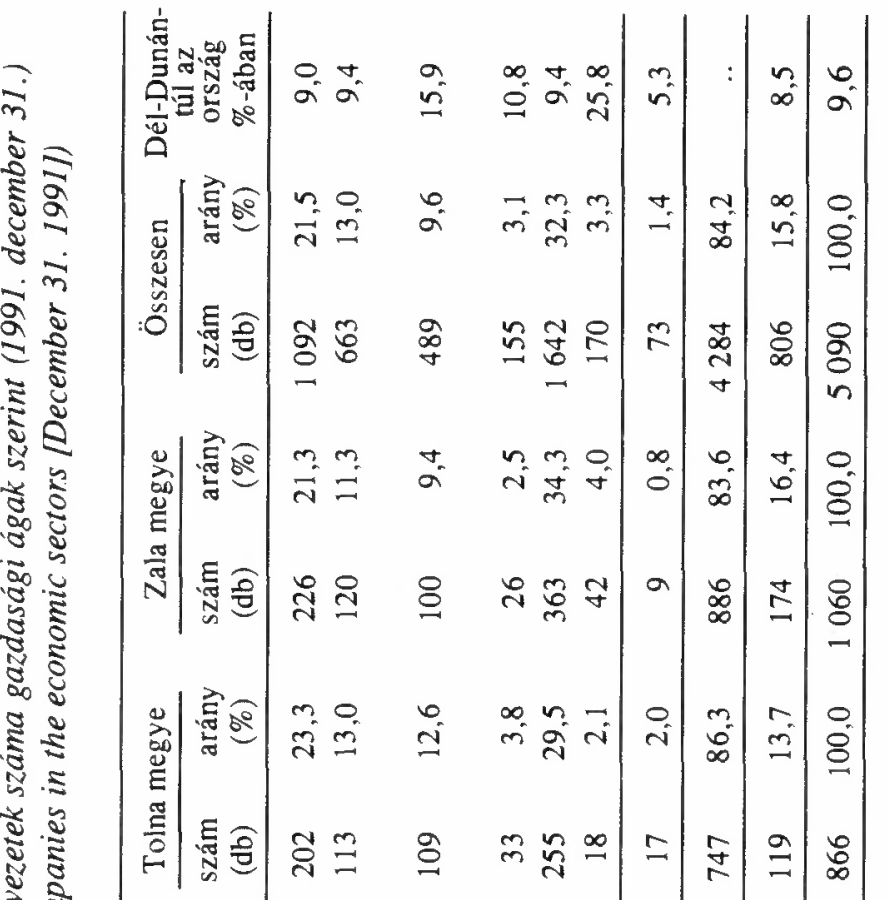

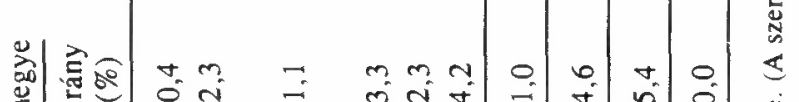

$\therefore 2$

$\pi$

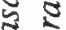

:

i.

$\overbrace{}^{\circ}$

突 ¿

$\stackrel{\square}{2}$

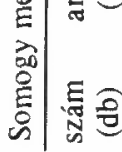

유느

$=$

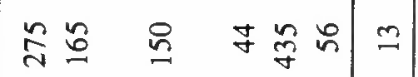

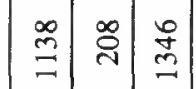

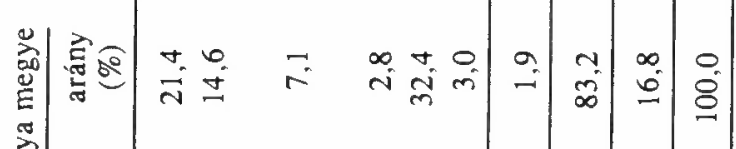

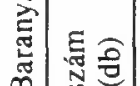

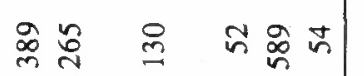

m)

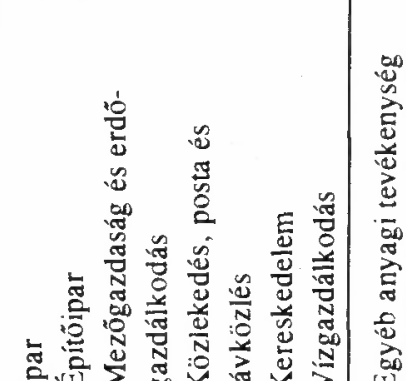

$\frac{m}{n} \tilde{c} \frac{\infty}{\infty}$

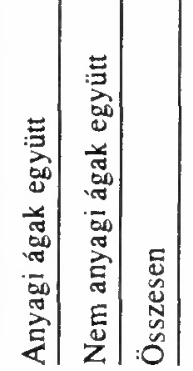

告 
Hrubi László: A Dél-Dunántúl gazdaságszerkezete és ipara.

Tér és Társadalom, 8. 1994. 1-2. 83-107. p.
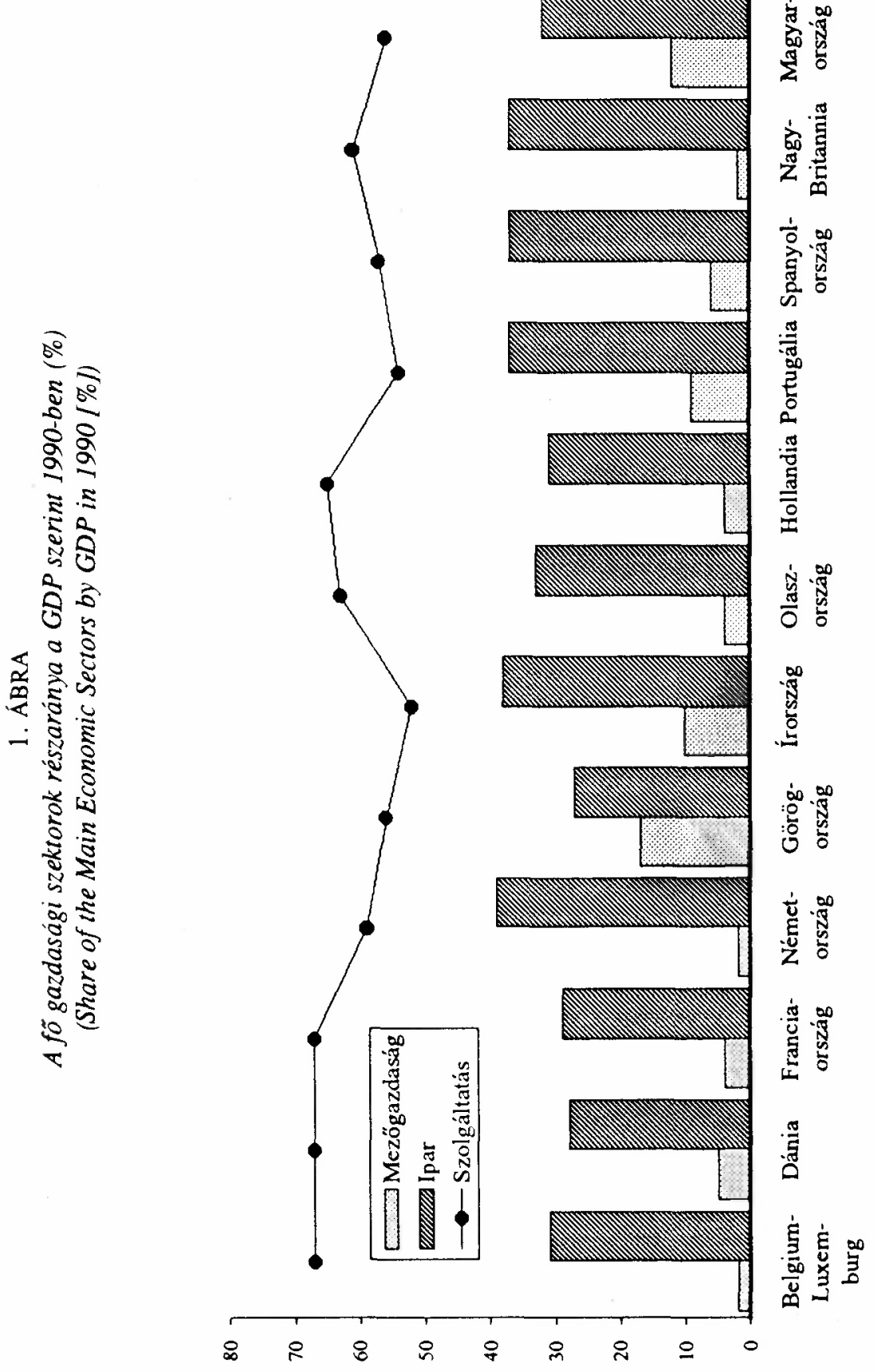

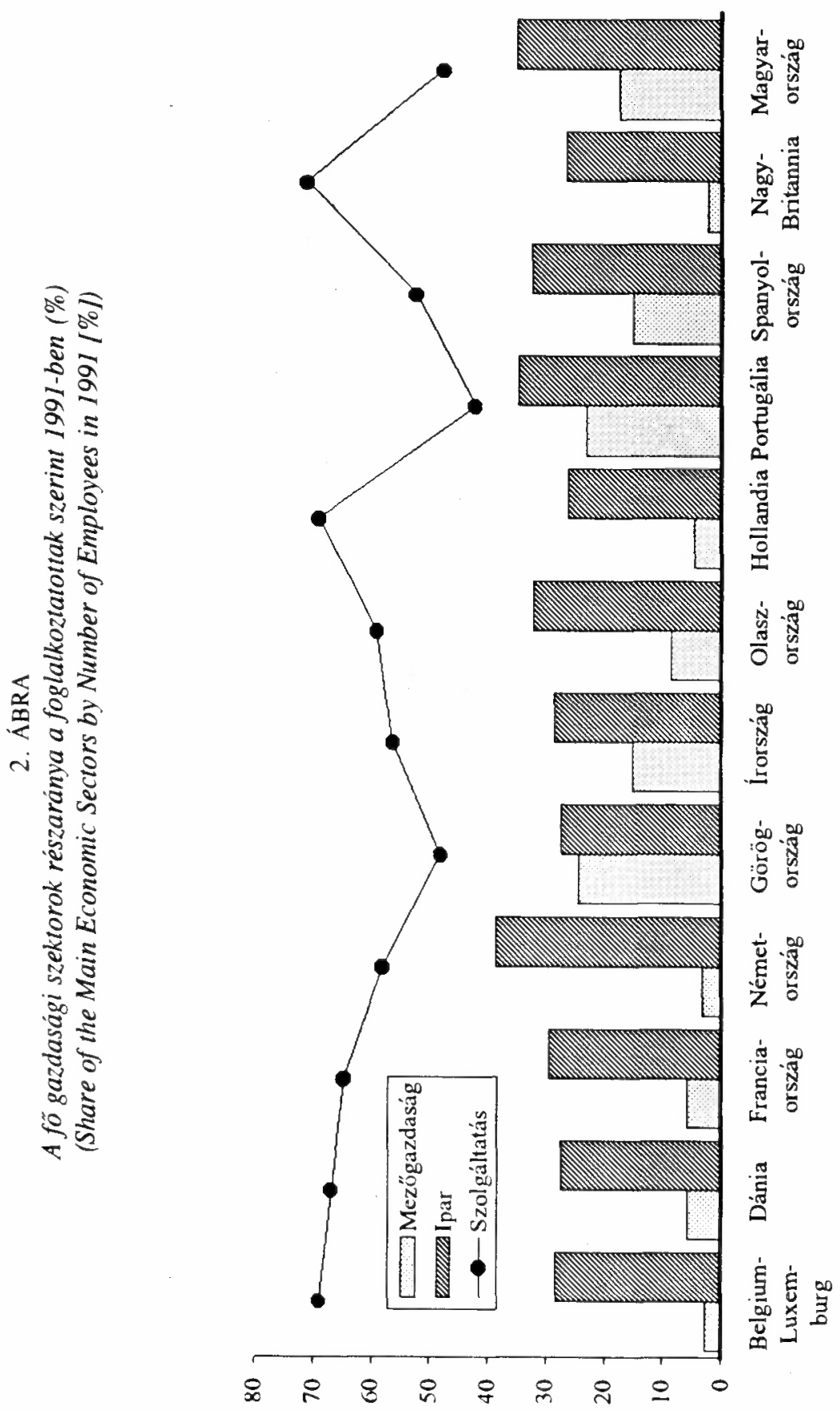


\section{TÁBLÁZAT}

A tercier szektorban foglalkoztatottak arányának változása

(Change of the rate of those employed in the tertiary sector)

\begin{tabular}{lcc}
\hline Megnevezés & A tercier szektorban foglalkoztatottak aránya (\%) \\
\cline { 2 - 3 } & 1980-ban & 1990 -ben \\
\hline Baranya & 39,7 & 45,9 \\
Bács-Kiskun & 32,3 & 37,3 \\
Békés & 34,3 & 40,8 \\
Borsod-Abaúj-Zemplén & 35,5 & 42,9 \\
Csongrád & 36,9 & 44,4 \\
Fejér & 35,0 & 43,1 \\
Gyốr-Moson-Sopron & 36,3 & 44,7 \\
Hajdú-Bihar & 38,3 & 43,9 \\
Heves & 36,3 & 43,4 \\
Jász-Nagykun-Szolnok & 37,8 & 41,3 \\
Komárom-Esztergom & 32,4 & 39,7 \\
Nógrád & 34,0 & 39,2 \\
Pest & 37,8 & 44,9 \\
Somogy & 40,0 & 48,9 \\
Szabolcs-Szatmár-Bereg & 37,3 & 44,0 \\
Tolna & 35,0 & 40,2 \\
Vas & 39,8 & 45,2 \\
Veszprém & 36,1 & 43,5 \\
Zala & 36,1 & 43,7 \\
\hline Budapest & 51,3 & 60,6 \\
\hline Ország összesen & 39,3 & 46,5 \\
\hline
\end{tabular}

Forrás: Népszámlálás. 1980., 1990. (A szerzô saját számítása.)

A külföldi tốke részvétele a régióban egyelöre csak az alkalmazkodás, a fejlốdés esélyét növeli a gazdasági egységeknél. 1992-ben az egy társaságra jutó hozzáadottérték és a vegyesvállalati arány között nem volt egyértelmũ összefüggés (3. ábra). Tendenciájảban tulajdonképpen csak Budapestnél, illetôleg Vas, Gyôr-Moson-Sopron és Zala megyénél fedezhetô fel ilyen kapcsolat.

Részben e közismerten elöljáró térségekben, de még inkább másutt a külföldi részvétel eddig a kisebb szervezeteket ,,célozta meg" tömegesebb módon, illetôleg relatíve kisebb tốkerészesedéssel tette ezt. Ha a külsõ tôke bevonása egy-egy cégnél nagyobb hányadra tesz szert, esetleg ,sorra kerülnek” a nagyobb, de az alkalmazkodás esélyével is rendelkezô társaságok, a külföldi résztulajdonlás és a potenciál múködése között bizonyára szorosabb kapcsolat alakulhat ki. 

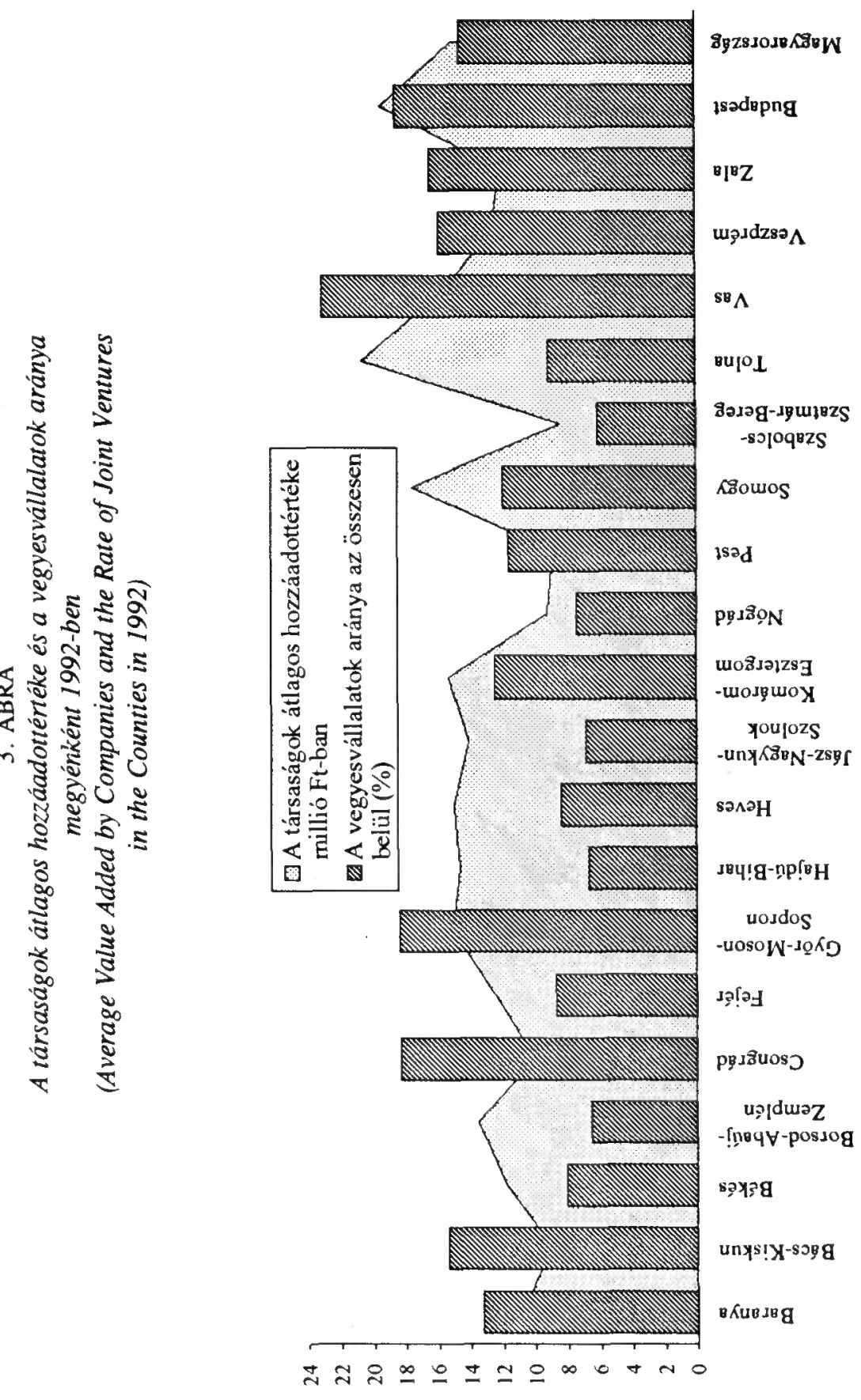
A külföldi tổke beépülésének ez a kiteljesedése irányzatában már 1990-1991-ben is kimutatható: a vegyesvállalatok számbeli gyarapodásának ütemét meghaladó a vegyesvállalatok átlagtổke-növekedésének a dinamikája. A tendencia a dél-dunántúli régió megyéiben is - hozzávetôleg az ország egészét jellemzõ ütemben - érzékelhetô. A régióban a vegyesvállalatok átlagos tôkenagysága 1991 végén mindazonáltal nem éri el az országos átlagot. A legközelebb Baranya, majd Zala került ehhez (az országos átlag 67, illetve 62\%-os értékével), míg Tolnát és Somogyot az átlaga a három legalacsonyabb értékú megye közé sorolja be az országban. Egyébként a szervezetek eloszlása és az átlagos tổkenagyság közötti kapcsolat szinte ellentétes mozgást végez.

Összefoglalva, a dél-dunántúli régió gazdaságszerkezete lassan változik, továbbra is jellemzõ az erôsebb agrár jelleg. A vâllalati szervezet átalakulása, az alkalmazkodás részben az örökölt, részben az ország jelenlegi gazdasági potenciálján belüli súlya, szerepe miatt egy kissé megkésett. A külföldi tôke megjelenése az országos átlagnál kevésbé jelentốs gyakoriságú, és elsôsorban a kisebb egységeket érintette. A szerkezet és szervezet váltása legelôrébb a harmadik szektorban jutott, az iparban egyelổre mérsékeltebb az átalakulás dinamikảja, míg a mezốgazdaságban a vizsgált év még a ,,vihar elốtti" állapotot tükrözi, ahol a szelekció elsôsorban a gyenge adottságú megyékben mutatkozik.

\section{A Dél-Dunántúl ipara}

A dél-dunántúli megyék iparának szerkezetét a különbőzōségek és hasonlóságok egyaránt jellemzik. Az eltérés az, hogy a sajátosságok egyszersmind az ország egészét véve is különös és örökölt vonások, míg a hasonlóságok zömmel mintegy belesimulnak az ország egészét leíró szerkezeti jegyek alkotta képbe (4. táblázat).

Baranya megyében a bányászat, és ,,természetes" velejárójaként a (főleg nổi munkaerốre települt, de hagyományokon is nyugvó) könnyũipar a domináns, feltûnôen alacsony viszont a gépipari ágazat aránya. A két vezetô ágazat súlya 1980 és 1990 között csökkent ugyan a foglalkoztatásban, de még így is meghatározzák a megye ipari szerkezetét és potenciálját. A strukturális eltolódás zömmel az élelmiszeripar javára történt, a minimális arányú gépipari ágazatot azonban továbbra is alig érintette.

Somogy megyét a gépipari és élelmiszeripari ágazat magas aránya különbözteti meg a régió többi részétốl. A megye iparszerkezetében 1980 és 1990 között érdemi változás nem történt, a jelenleg is meglevô ipari struktúra döntôen a 70-es években alakult ki. 
Tér és Társadalom, 8. 1994. 1-2. 83-107. p.

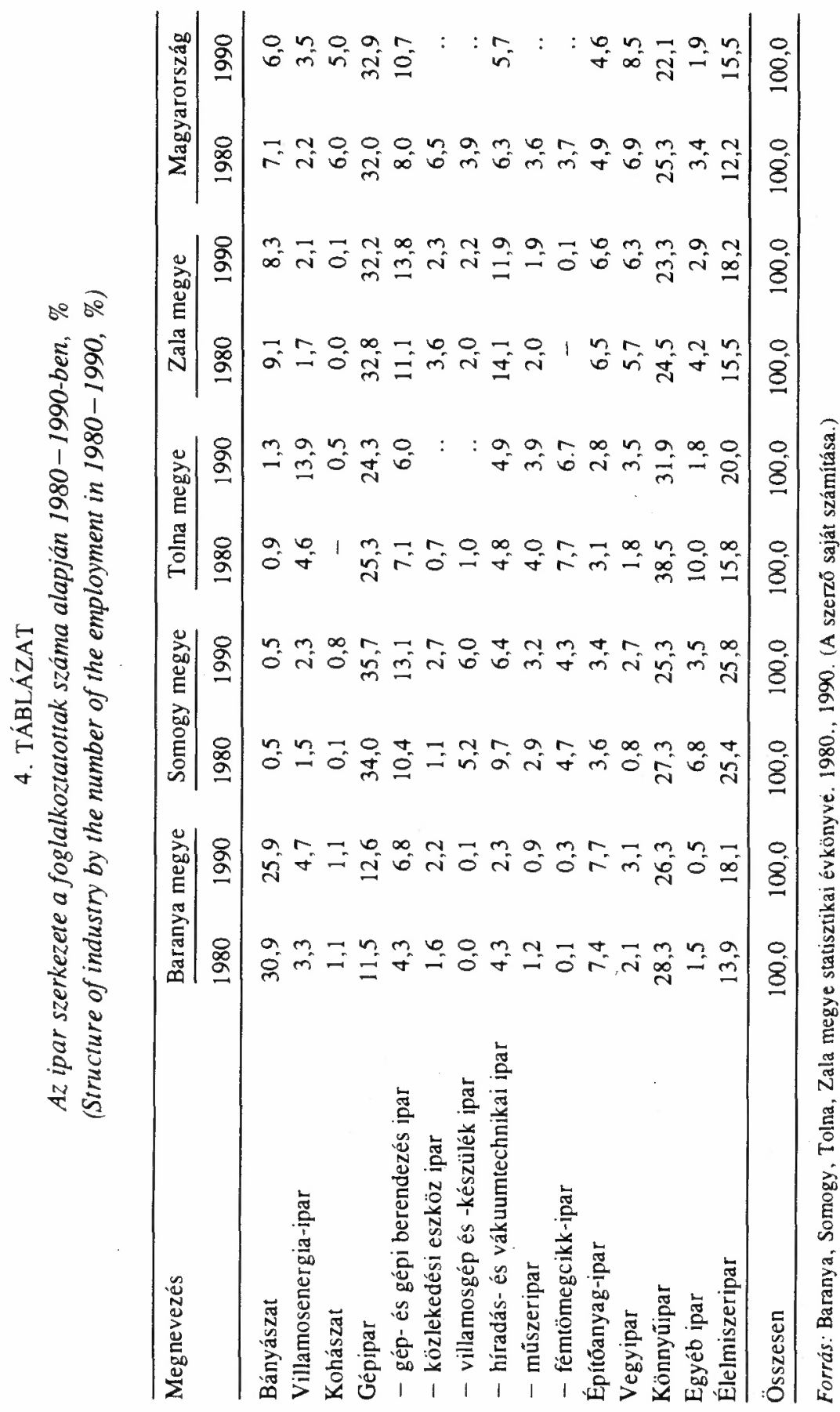


Tolna megyében természetesen az energiaipar mutatója a legkarakterisztikusabb: a paksi atomerổmũ erôteljesen rányomja bélyegét a megye ipari palettájára, nem kis mértékben torzítva is azt, a valóságosnál kedvező̉bb összképet mutatva. Az energiaipart a változások ellenére egy rendkívül erốs könnyưipari foglalkoztatás egészíti ki meghatározó elemként. A szerkezetmódosulási irányok közül a könnyưipar jelentôs visszaesése mellett még az egyéb ipar korábban ugyancsak egyedi szerepének minimálissá válása és a gépipar némi csökkenése a figyelemre méltó egyfelől, a villamosenergia-ipar és az élelmiszeripar gyors térnyerése pedig a váltás növekedési irányaként másfelôl. Tolna megyében az atomerômû mellett ebben az évtizedben jön létre - elsôsorban Szekszárdon és környékén - egy olyan élelmiszergazdasági vertikum és koncentráció, amely Szekszárdnak egy egyedülállóan sajátos gazdasági szerepkört kölcsönöz a magyar városhálózatban.

Zala megye iparában - ahol Tolnához hasonlóan még a 80-as években is nốtt a foglalkoztatási szerepe - érdemi strukturális elmozdulás Somogy megyéhez hasonlóan nem volt a vizsgált periódusban. Az élelmiszeripar arányának növekedése mellett lassú ütemben csökkent a gépipar és a könnyũipar súlya. Az utóbbi azután 1991-ben megint felszökött, olyannyira, hogy még az 1980-as szintet is meghaladta.

Az ipari szervezeteknek döntôen a városokba koncentrálódása a 80-as években nemigen mérséklő̉ött, sôt a várossá nyilvánítás révén a falusi iparbázisok egy jó része is városi lett

Baranya megyében - ahol Pécs súlya, sôt Komlóval és a környék falvaival együtt a túlsúlya döntố volt és maradt - tapasztalható viszonylag a legnagyobb mérvũ elmozdulás a községi ipar javára. Igaz persze, hogy elsôsorban Pécsvárad, Szentlôrinc és talán Sellye az elôidézôje ennek, ahol a várossá válás késổb következett vagy következik be. A másik megjegyzés peđig az lehet, hogy a községi ipart - a beremendi cementgyảron kívül - zömmel pécsi vagy komlói székhelyũ cégek bedolgozó (könnyưipari) telephelyei alkotják, eléggé instabil helyzetben.

A baranyaihoz hasonló ,,egyközpontúság" a jellemzố még Somogy megyére, ahol a községekbe települt ipar foglalkoztatottainak az aránya a legalacsonyabb a négy megye közül.

Tolna megye sajátossága - településszerkezetével is összefüggésben - a községi ipar viszonylag nagyobb súlya, mégpedig a nem potenciálisan várossá váló falvakban. Ennek ellenére itt is csökkent már 1990-re a falusi iparban dolgozók részaránya.

Zala megyét területi értelemben a két megyei jogú város, és ennek folytán a két városra települô kettôs ipari pólus teszi sajátossá. A falusi ipar foglalkoztatási szerepe lényegében csak a várossá nyilvánítás révén változott.

Az adatokat szemlélve tehát nincs érdemi területi terjedés az iparban, sôt a számottevôbb iparral renđelkezô községek várossá is válnak. A várossá válás útja továbbra is az ipar súlyához kötôdik. Ilyen értelemben az iparhoz kapcsolódó fejlödési várakozás praktikusan jelen van, sốt tapasztalati úton még további impulzusokat is kap. 
Az 1990 utáni években a községi ipar foglalkoztatottainak aránya a statisztika szerint erốs hullámzásnak indul. A lemenô irányt a fióktelepi jellegbổ származó sebezhetốség, egyoldalú függés és kiszolgáltatottság táplálja. Az anyavállalatok a szigorodó környezetben elsôként ezeket áldozzák fel (a régióban is), esetenként az anyacég túlélésére használva fel az így visszaforgatott vagyonrészt, vagy éppenséggel a költségmegtakarítást. Az időnkénti felfutást pedig a (néha külföldi) bedolgozás és bérmunka adja, olykor idốszakos telepi mũködést eredményezve. Noha a régióban az egész ipart egy nagyfokú átmenetiség, a privatizáció késése és a tényleges szerkezet- és mũködésváltás elhúzódása jellemzi, a falusi ipar még ehhez képest is labilis. Ráadásul mindez olyan helyzetben következett be, amikor széthullik a mezổgazdaság szervezete is, hogy majd új tulajdonosi és mũködési rendszer szerint újjászervezôdjön.

Az úgynevezett iparosodottság (az iparban foglalkoztatott népesség aránya) Somogy megyét kivéve számottevôen nem különbözik az országos átlagértéktốl. Mennyiségi értelemben a régió így közepes fejlettségünek minôsíthetô. Az ipari foglalkoztatottak bruttó átlagkeresete pedig - megint Somogy megyétől eltekintve - meg is haladja az országos szintet. Emellé azonban feltétlenül oda kell tennünk a visszautalást a hozzáadottérték kapcsán vázolt helyzetre. A kettô együtt a szerkezetváltás elhúzódására vonatkozó megállapításunkat támaszthatja alá. Ha ide még felsorakoztatjuk a külkereskedelmi célra történô értékesítés általában alacsony - Baranyában egyenesen kirivó - arányát, a kép a mozaikszerũ adatbázis ellenére viszonylag teljessé válik.

Összefoglalóan, a régió iparát lassú szerkezeti változások jellemzik. Általános elemként a könnyũipar súlyának csökkenése és az élelmiszeripar szerepének növekedése emelhetố ki, az örökölt iparszerkezeti sajátosságok némileg mérséklődố arányú továbbélése mellett. Többségében városi iparról van szó, a falusi ipar hálózata egy-két kivételtổ eltekintve még a nem túl fejlett országos szinthez képest is elmaradásokat mutat, és meglehetősen labilis helyzetben van.

\section{A régió gazdaságfejlesztési stratégiájának alapvonásai}

A területi gazdaság szerkezeti alkalmazkodása, váltása kapcsán klasszikus dilemma $a$ folytonosság és a radikális átstrukturálódás ellentmondása. A probléma alapvetõen az, hogy egy térség gazdasága a kialakult bázisán fejlődhetne tovább, ugyanakkor a piaci viszonyok által meghatározott modernizáció egy merõben új struktúrát igényelne, mégpedig viszonylag gyorsan, amely kevésbé alapozódhat a meglévố bázisra.

Ez az alapkérdés a Dél-Dunántúl gazdasági stratégiája kapcsán is felvetôdik. Egyszerũsítve a képletet: a realitásként a jelenlegi bázison kibontakozó szerves fejlődés jövôképe és a piaci viszonyokból származtatható kívánatos jövõkép között számottevô különbség van, a jelen termék- és szervezetstrukturrája alapjában más, mint a célként megfogalmazható termék- és szervezetstruktúra. A Dél-Dunántúl mai exportjában megjelenõ 
termékek például sok esetben alkalmatlanok arra, hogy egy fejlesztési stratégia elemei lehessenek, arról nem beszélve, hogy ezek aránya az értékesítésen belül még hazai összevetésben is alacsony, az exporthányad a régió gazdaságában gyenge színvonalú.

Nyilvánvaló, hogy sem elvi, sem gyakorlati okokból nem lehetséges az, hogy a stratégiaként vázolandó program ne a szerves fejlớdés útját, azaz a jelen struktúrából kinövô, azon alapuló fejlốdést vázolja fel. A stratégia ily módon szükségképpen a kis lépések, a fokozatos diverzifikáció programja, amely a hosszabb távon megvalósítható szerkezeti váltás folyamatát vetítheti elốre.

A fentiekbốl adódik a stratégia második kiindulási pontja, nevezetesen, hogy a területi fejlơdés útja elsôdlegesen a területi gazdaság erōsödése, fejlôdése, amely magából a gazdasági szférából, a vállalatokból és vállalkozásokból nõhet ki. A területi gazdasági potenciál rehabilitációja, új alapokra helyezôdése a vállalati-piaci szféra vállalkozási-üzleti alapon történô mozgása eredményeként mehet végbe. Minden központi vagy helyiterületi beavatkozás külsôdleges jellegú, de szükséges és feladata a támogatások, kedvezmények (ösztönzốk és szabályozások), valamint a területi fogadókészség és a környezet alakítása révén a mũködố tốke területi és ágazati mozgásának a befolyásolása. A központi és a helyi-területi önkormányzati beavatkozás célja döntõen az, hogy az egyébként a települési, területi érdekek szempontjából kevéssé érzékeny gazdasági szféra számára közvetítse ezeket az érdekeket, és piackonform, zömmel pozitív (és csak végsô esetben adminisztratív) befolyásolással érvényre is juttassa azokat.

E funkció tehát a területi gazdaság fejlổésének, folyamatos - a piaci viszonyokhoz történố - alkalmazkodásának elősegítése a belsõ erőforrások hasznosítása, a külsõ támogatások és ösztönzổk célirányos felhasználása révén, a területi-települési adottságok és feltételek figyelembevételével és a hasznosulásuk érdekében.

A funkcióhoz kötôdố területi érdek három alapmomentuma a következõ:

- a területi munkamegosztás elmélyítése, a regionális piaci viszonyok kibontakozásának az elốmozdítása;

- a térség közösségi és egyéni jövedelemforrásainak a gyarapodása;

- a népesség foglalkoztatása.

Amennyire evidensnek tûnổ érdek a jövedelem és a foglalkoztatás, annyira nem az többek között a regionális fejlődés eddigi modellje miatt - a területi munkamegosztás és kooperáció, ezért ezt kell a stratégia harmadik meghatározó pontjává kiemelni. A versenyképes gazdaság kiépülése a régióban a területi gazdaság regionalizációjával, a regionális meghatározottság jelentôs erösödésével mehet végbe. A területi kooperáció alapja a regionális fejlôdéshez kötôdố érdekközösség lehet, amely egyre inkább anyagijövedelmi természetũ lesz, tekintettel arra, hogy a régiók között is egyre határozottabb verseny bontakozik ki. Az érdekközösség nem más, mint az egyêni, a közösségi és a helyi-területi fejlổés, vagyongyarapodás és anyagi értékképzõdés mind szorosabb összekapcsolódása és valós forgalmi-piaci manifesztálódása. A társadalmi-gazdasági fejlódés, a települési (infrastrukturális) környezet fejlettsége, a gazdasági egységek viszonylag stabil helyzete, az új vállalkozások terjedése az adott térségben (településen) 
egyaránt felértékeli a magán-, közösségi és vállalati-üzleti vagyont, növeli a piaci forgalmi értéket (ez az úgynevezett forgalmi értéknövekedési hatás).

Persze a verseny a régión belül a körzetek, sốt települések szintjén is megjelenik, de ez belátható idổn belül alárendelôdik a régiók közötti versenynek. A versenyben való előrejutás - azaz a fejlôdés - pedig minden szereplô jövedelmi-vagyoni pozícióját emelheti (miként fordított esetben le is értékelheti).

A regionális gazdaság és a regionális piac fokozatos kibontakozásával, épülésével ugyanis a területi gazdasági fejlôdés és szerkezet egyre inkább a belsô erôk mozgósítására támaszkodik, mert a tartós fejlôdôképesség megteremtése (egyfajta regionális fejlốdési egyensúly kialakulása és fenntartása) éppen a helyi adottságok, feltételek és lehetôségek bázisán, azokat maximálisan (vagy azt közelítốen, optimálisan) hasznosítva és számításba véve képzelhetô el. Továbbá, ezen az úton teremtốdhet meg a feltétele annak, hogy a regionális gazdaság folyamatos alkalmazkodóképessége, szerkezeti adaptálódási készsége létrejöjjön a régió keretein belül, elkerülendô, hogy a folyamatosan újratermelổổ váltási kényszerek regionális válsághelyzeteket idézzenek elô.

A regionális munkamegosztási és kooperációs rendszer csomópontjait fejlôdési klasztereknek nevezhetjük, amelyek a regionális fejlesztési stratégia alapelemeit adják. Ezek a klaszterek olyan sưrũsödési pontok a régió gazdaságában, amelyek:

- egyfelổ ágazati és funkcionális kötổdésben (egyfajta sajátos vertikális kapcsolatban) álló gazdasági egységek láncolatát jelentik versenyképes végtermék vagy szolgáltatás elôállitása, jövedelmezỗ termelési folyamat révén, elsổdlegesen a régió belsõ erőforrásaira támaszkodva és azt hasznosítva;

- másfelốl a régió gazdasági-szolgáltató egységei között egy olyan kapcsolati hálót, amely a piac közvetlen hatás-közvetítését is biztosithatja, a közös érdek alapján álló információáramlást és a piaci impulzusokra történổ reakciót egyaránt.

E klaszterek elsõdlegesek, de nem kizárólagosak a régió gazdasági fejlôdésében. Leginkább rövid távon lesz ez igaz, hisz a piaci viszonyok alapján kiépülố regionális munkamegosztás egy folyamat eredménye. Ma még sok helyütt ott sincs régión belüli kooperációs kapcsolat, ahol egyébként az kézenfekvõ lenne (például bổipar-bôrruházati és kesztyũipar, fafeldolgozás-bútoripar stb.), elsốsorban azon okból, hogy a gazdaság rendszere korábban a nemzetgazdaság szintjén ágazati munkamegosztást követve alakult.

A területi gazdaság regionalizációja ugyanakkor nyitott gazdasági rendszert jelent, tehát a régión kívüli kapcsolatok is tartósan fennmaradnak, bizonyos szférákban pedig meghatározók is lehetnek (ez a regionális adottsạ́gok és feltételek következménye).

Ha a területi-települési gazdaság fejlódésében résztvevõ aktorokat a perspektíváról kérdezik, szinte sztereotíp válaszokat adnak: a fejlődés-fejlesztés legföbb akadálya a tôkehiány, a magas hitelkamat (infláció), a nagymérvũ jövedelemelvonás és a kisebb jövedelmezôség, valamint - másodlagosan - a hagyományosan értelmezett infrastruktúra fejletlensége. Nincs okunk kételkedni abban, hogy ez így igaz. A régió fejlesztési stratégiája az elsổdlegesként említett tényezõkkel nem foglalkozhat, azok a makrogazdasági 
keret elemei, peremfeltételek a program számára. A hagyományos infrastruktúra hiánya már a stratégia része lehet, mint ahogy arra más helyen ki is térünk.

A lehetséges klasztereket vizsgálva azonban körvonalazható egy olyan szũk keresztmetszet, amely a fentebbi korlátokon túl mutatkozik, fontossága egyáltalán nem másodlagos és akár a regionális fejlõdés ösztönzésének, elốmozdításának stratégiai területe is lehet. Bárhogy vizsgáljuk ugyanis a lehetséges klaszterek kialakíthatóságát, vagy kialakulásának az esélyét, a számba vehetổ területi termelố-szolgáltató egységek láncolata a viszonylagos fejletlenség, a korábbi gazdasági-szerkezeti rendszer miatt - két stratégiailag fontos ponton hiányos. Az egyik alapvetõ gond a láncolat elsô szakaszának a hiánya, amit a szükebben vett innovációs rendszernek nevezhetünk. Mind a gyártmány-, mind a gyártásfejlesztés a Dél-Dunántúl gazdaságában rendkívül fejletlen. A korábbi, zömmel telephelyi jellegũ szervezeti rendszer még a nagyobb egységek esetében sem alakított ki e célra belsô egységeket. A háttérben szükséges $\mathrm{K}+\mathrm{F}$ tevékenység a DélDunántúlon még hazai összevetésben is fejletlen, a legnagyobb elmaradás pedig éppen a mũszaki fejlesztési szférában tapasztalható. Eddig nyilvån a közgazdasági értelemben vett szükségesség sem jelent meg, a jelenlegi szerkezetváltási kényszer viszont elodázhatatlanná teszi a lehetố leggyorsabb kiépülését.

A másik alapvetô hiány a láncolat végén a piaci szervezet, a marketing apparátus. Ez két irányban is komoly hátrányt jelent. Az egyik maga az értékesítés megszervezése, és ezen belül különösen a külpiaci eladásé. A fejletlenség oka itt is ugyanaz, mint a fejlesztésnél, sỗt voltaképpen a közvetítô beiktatásával alkalmanként pótolt belsố hiány esetében ugyanaz a függés, kiszolgáltatottság jött létre, mint a ,,fejlesztési importnál' . A másik hiányosság pedig a piaci információk beszerzésének a problémája, amelynek elégtelen volta elöbb-utóbb a teljes gazdasági tevékenység fejlôdését blokkolhatja.

A láncolat elején és végén egyszerre mutatkozó hiány azt jelenti, hogy a gazdasági egységek többségénél ez a két pont a szũk keresztmetszet, továbbá, hogy ezen a téren elkülönült üzleti-szolgáltató szervezet (infrastruktúra) nem alakult ki.

Az új vállalkozások érdemi változást ezen a téren nem hoztak. Jellemzô, hogy a termelỗ jellegũ új vállalkozások részaránya kicsi (hozzávetôlegesen a társas vállalkozások negyede, ötöde), a többségük kis létszámú szervezet, amely viszonylag egyszerũ termék(ek) elōállítására vállalkozik. Egy 1992-ben Baranya megyében végzett felmérésünk szerint például a 140 ipari ágazathoz sorolt vállalkozásból $81,4 \%$ a termelés minden fázisát maga végezte, nem volt termelési kooperációs kapcsolata (egyébként a kooperációs kapcsolatok jellemzõ formája eme felmérés szerint a bérmunka, ami ugyancsak nem igényel különösebb komplexitást a vállalkozási funkció esetében).

A fejlesztés és a piaci szervezet kiépülésében eddig a külföldi tõkével alapitott vegyesvállalatok sem okoztak, ,áttörést", a létrejött vegyesvállalatok többsége a régión belül nem támaszkodik kooperációra, gyakorlatilag telephelyszerũ tevékenységet végez. Az emlitett két funkciót az anyacég látja el.

Ami a piaci szolgáltatásokat illeti, a hiány érzékelhetốbb és kézzelfoghatóbb, tehả kezdeményezések is vannak: érdekképviseletek, igazgatási szervezetek stb. próbálnak 
közvetíteni, piaci kapcsolatokat elômozdítani, de néhány új vállalkozás is akad már erre a funkcióra. Különösen fontos lenne a külpiaci értékesítéssel kapcsolatos ilyen irányú közvetítés, továbbá, hogy ez üzleti-szakmai alapon történjen.

A régió gazdasága fejlôdésének lehetséges fốbb csomópontjait, klasztereit elemezve még egy alapvetố sajátosság emelhetố ki. Egyelôrre nincs, és belátható idôn belül nem is látszik kialakulni olyan klaszter, amely a régió gazdaságának a leginkább sajátos vonása lehetne, a regionális fejlôdésnek mintegy fazont adna. A korábbi ilyen jellegũ elemek (például a bortermelés, a szén-, urán-, kốolajbányászat, a könnyưipar egyes ágazatai, a turizmus stb.) vagy a piaci viszonyok változása, vagy saját fejlôdési korlátaik miatt elvesztették ezt a szerepüket, ma legfeljebb egyik elemévé válhatnak egy új struktúrának. Újak pedig nincsenek, mivel a ,gazdasági félperiféria" értelemszerũen nem produkált új pólusokat.

A régió gazdasági fejlốdése ezért egy diverzifikált szerkezetũ potenciál bázisán mehet végbe, ahol láncolatszerũ kooperatív klaszterek és egyedi fejlốdési ,,pontok” egyaránt elôfordulnak, anélkül, hogy akár a régió, akár az azon belüli területi egységek esetében valamelyik is meghatározó, generáló elem lenne.

A fejlôdés ágazati szerkezete is a diverzifikáltságot tükrözi. Az ipar nem veszít jelentôségébổl, bár a foglalkoztatásban betöltött szerepe mérséklôdik. Mivel ezen belül az egyik lehetséges fejlốdési csomópont az élelmiszeripar, a mezógazdaság nagyobb arányú szerepcsökkenése sem prognosztizálható. Az utóbbi esetében további indok lehet az is, hogy a régió egy jelentõs része gazdaságilag elmaradott rurális körzet, ahol a speciális, elmaradottságot kezelô programok miatt még sokáig nem nélkülözhetô a mezôgazdasági tevékenység.

A szerkezeti módosulásnak voltaképpen egyetlen új eleme a tercierizálódás lehet. Az európai fejlôdési trendek alapján a folyamat egyfelöl szükségszerũ, másfelôl a régió eddigi fejlôdését már jellemezte egy mérsékelt tempójú, ilyen irányú átrendezôdés. A primer és szekunder szférák létszám- és szervezetleépülésével a tercier szférában foglalkoztatottak és a szervezetek száma gyarapodott, ami arányában azután - a leépülési háttérrel - talán nagyobbnak is tûnt statisztikailag, mint amilyen valójában.

A másik ok, ami miatt az eddigi aránynövekedésnél mérsékeltebbnek kell feltételeznünk a tercier szféra regionális gazdasági szerepének a felértékelôdését, az az, hogy a szolgáltatási szférán belül - a hiányos statisztikai adatok miatt csak becslés alapján - a gazdasági-üzleti szolgáltatások kevésbé gyorsan izmosodtak, az adminisztratív és a költségvetési szféra kiterjedése mindenképpen nagyobb volt.

A tercierizáció folyamatának kibontakoztatása mindazonáltal a régió fejlôdésének egyik alapterülete lehet, és mint ilyen, a stratégia egyik legfontosabb fejlesztési eleme. Egyrészt az infrastrukturális környezet fejlôdése és az ezt mũködtetô szolgáltatás felfutása a gazdasági fejlốdés egyik alapfeltétele (ezen belül a közlekedés, hírközlés és a kommunális ellátás bizonyulhat a regionális növekedés ,,peremfeltételének”). Másrészt - és a stratégia szempontjából nem kevésbé fontos módon - a tercierizáció, és azon belül a gazdasági-üzleti szolgáltatások bõvülése jelentôsen gyorsíthatja azt a folyamatot, 
amelyben a régió gazdasági egységei a regionális piac kibontakozása, a gazdaság regionalizációja irányában fejlődnek, és erõs belsõ kooperációs hálózattal rendelkezô, piaci alapon múködố és arra reagáló, regionálisan meghatározott gazdasági bázis jön létre. llyen értelemben a tercierizációs folyamat lehet az a szféra, ahol a szũkebben vett gazdaságon kívüli szereplốknek piackonform módon a legtöbb lehetôségük adódhat a regionális fejlõdés elốmozdítására.

A tercier szférához tartozó gazdasági szervezetek sokasodása, differenciálódása a piacgazdaság igényelte munkamegosztás terméke. E szervezetrendszer létrejöttének támogatása, kezdeményezése, gyorsítása azonban visszahat a gazdaságfejlôdési, -épülési folyamatra, akceleratív szerepet játszik, ezért igen hatásos közvetett területi növekedést élénkítố eszköznek tekinthetô. Alapját, szükségességét az adja, hogy a területi gazdasági növekedésben és szerkezetalakulásban (-alkalmazkodásban) a kis- és középüzem méretũ szervezetek játsszák a meghatározó szerepet, ahol a vállalati teljes funkcióhoz kötốdô teljes körũ belsố apparátust a vállalkozás nem bírja el, de a mũködés nem is igényli ezt. Bizonyos vállalkozási funkciók szolgáltatássá specializálódnak (és koncentrálódnak), piaci termékké válnak.

A tercier szféra lehet a regionális fejlődést elômozdító stratégia egyik fổ intervenciós pontja.

\section{A kialakitható gazdasági klaszterek}

E program döntô eleme, hogy a gazdaságot nem csak ágazati vagy profitorientált megközelítésben vizsgálja, hanem vertikálisan és horizontálisan integrált, a régióban gyökerezố klaszterekben. E megközelítés segíthet abban, hogy a régió döntéshozói - a közösségi és magánszektorban egyaránt - olyan újszerũ stratégiai és taktikai döntéseket hozzanak, amelyek új pályára terelhetik a regionális gazdaság fejlốdését.

A programalkotás nehézségei az alábbiakban foglalhatók össze:

- a régióban termelt áruk piaca csak lassan nố;

- a verseny a világpiaci és az EU-ba való integrálódásunkkal erốsödik;

- a régió hagyományos komparatív elổnyei gyengülnek;

- a korábban a legnagyobb jövedelmet termeló bányászati klaszter hanyatlik és magával rántja a körzet gazdaságát is;

- a gazdasági szolgáltatások fejletlenek és maguk is támogatásra szorulnak.

Ezért a gyengülö komparatív elônyöket új versenyképes elemekkel kell kiegésziteni:

- új versenyképes gazdasági klasztereket kell kialakítani vagy reorganizálni;

- fejleszteni kell a helyi igényeket kiszolgáló gazdasági infrastruktúrát;

- az EU piacára kell koncentrálni (ami ott versenyképes, az bárhol eladható a világon);

- erổsíteni kell a közösségi és a magánszféra együttmüködését. 
Az élelmiszeripari klaszter

Az élelmiszeripari klaszter - ráépülve a részlegesen már meglévố vertikumra - a Dél-Dunántúlon lényegében a teljes folyamatot átfoghatja a végtermék értékesítésével bezárólag.

Elemei:

- élelmiszergazdasági kutatás, fejlesztés, tanácsadás;

- mezõgazdasági termelés (kis- és közepes méretû, egyéni és társas vállalkozások);

- élelmiszeripari feldolgozás;

- felvásárlási, ellátási rendszer (integrációs szervezet, amely a végtermék elôállítója is lehet);

- értékesítési, beszerzési szervezet, amelyen belül a külpiaci értékesítés érdemel külön kiemelést; ez a fokozat sem feltétlenül önálló szervezet, kötôdhet a végtermék elóállításához.

A klaszter alapjában véve négy területen jöhetne létre:

- a tejtermelésben és tejfeldolgozásban,

- a húsiparban,

- a bortermelésben,

- a zöldség, gyümölcs feldolgozásban és a tartósítóiparban.

A legkedvezôbb esélye a tejvertikumnak lehet. A tejtermelésnek hagyománya van a régióban, viszonylag fejlett gyártmány- és gyártásfejlesztési kutató bázissal rendelkezik. A fổ gond a teljes vertikumban most zajló tulajdonosi szerkezetváltás (privatizáció) következtében mutatkozó bizonyos dezorganizáció.

A DRI európai konjunktúra- és piacelemzése alapján ugyan az Európai Unión belül a tej- és tejtermékek piacának csak gyenge növekedése prognosztizálható, viszont a magyar vállalatok piaci lehetổsége ezen belül közepesen erôs. Komoly versenyhelyzet jellemzi a tej és tejtermékek forgalmát, mind az Unióbeli, mind pedig az EFTA-országok termelőivel. A piacelemzés aláhúzza, hogy az eladhatóság szempontjából a döntõ tényezô az élelmezéshigiéniai szempont, a tej minõsége és a termelés körülményei, valamint a csomagolás. Kedvezô a Dél-Dunántúl pozícióját illetôen az, hogy az Unión belül Olaszország és Görögország (azután Hollandia és Németország) a legfontosabb magyar exportpiac a tejtermékek számára.

A második terület lehet a sorban a bortermelés, azon belül a mecsek-villányi, a szekszárdi és a balatoni körzet (történelmi borvidék) számára.

A klaszternek a hagyományos vertikum képezné az alapját. E téren ugyancsak van a Dél-Dunántúlon kutatási-tanácsadó bázis. A legnagyobb gond az, hogy a klaszternél számba vehetố szervezetrendszer szinte teljes egészében felépülésre vár. A feltétlenül szükséges integrációs pontok a volt nagyüzemek válsága miatti szétesés következtében eléggé nehezen prognosztizálhatók. 
A bortermelés kapcsán a korábban is létezố vertikummal szemben e klaszternek az lenne az újdonsága, hogy a borturizmus révén az idegenforgalomhoz is kapcsolódna. Ebben a tekintetben fontos esemény lehet az 1996-os baranyai világrendezvény.

A harmadik ága az élelmiszeripari klaszternek a húsipar. Ennek a Dél-Dunántúlon külön kutatási-fejlesztési bázisa nincs, viszont a már privatizált és stabilizálódott nagy feldolgozók komoly termék- és gyártásfejlesztố tevékenységet folytatnak. Igaz, a négy lehetséges nagyüzem közül ez utóbbi csak a zalai és baranyai cégre áll, a szekszárdi és kaposvári bázisüzem kritikus helyzetben van. További alapprobléma az alapanyag-elởállítás, hiszen az állattenyésztés - a hagyományok és adottságok ellenére - a Dél-Dunántúlon is mély válságban van.

A DRI piac feltérképezése közepesen fejlổdõ EU-piacot, és azon belül erốs magyar piaci pozíciót mutat, 1991-es bázison. Az EU-import 12,8\%-át adta ekkor Magyarország. A prognózis tartható magyar piaci pozíciót mutat, Németország, Franciaország, Új-Zéland, Argentína és Brazília konkurenciájával. A pozíciótartás elsỡdlegesen az ár és állategészségügyi szempontok figyelembevételének a kérdése.

A legbizonytalanabb a zöldség-gyümölcs feldolgozás és tartósitás. A vertikum szinte teljes dél-dunántúli feldolgozó bázisa - a hứtôházakon kívül - felszámolás alá vagy annak közelébe került, az alapanyagtermelés teljes tulajdonosi-üzemi szerkezete pedig minden valószínũség szerint átalakul. Indokolt, hogy a klaszter szélesebb körũ összefüggésben kerüljön terítékre, mert a programozásnak ma a minimális fogódzói sem állnak rendelkezésre.

A helyzet már csak azért is sajnálatos, mert az EU piaci térképe a húskivitelhez hasonlóan igen kedvezố lehetne. Növekvố piacon a $2 \%$ körüli részesedésünk megtartására viszonylag erốs a pozíciónk, a mediterrán térség és Kelet-Európa konkurenciájával. Ennek kulcsa - a felmérés tanúsága szerint - az intenzív marketing-munka.

\section{Fakitermelés és -feldolgozás klasztere}

Az ipar ágazati szerkezetét illetốen szinte minden megyében lényeges fafeldolgozó kapacitások épülttek ki, erõsen változó eredményességgel, de különösebb kooperáció nélkül múködve. A klaszter a fakitermelés és -feldolgozás (épületfa, egyéb faáru és bútor) e gyakorlatilag sporadikus egységeinek fokozatos rendszerbe szervezôdésével alakulhatna ki.

Ennek piaci alapja a DRI felmérés szerint az EU-országokban meglenne, hiszen a fafeldolgozó iparban $1,2 \%$, a bútoriparban $2,7 \%$ volt a magyar import aránya, fejlõdố piac mellett, erõs magyar pozíciókkal. Természetesen itt is nagy a konkurencia, hisz a hagyományos skandináv vetélytársak mellett a kelet-európai országok is elớretörtek. Mindkét feldolgozási irányban az ár a sikeres szereplés kulcsa, a hagyományos feldolgozásnál azonban az újrahasznosítással, a bútoriparnál pedig a formatervezéssel párosulva. Mindkettổ nagyon gyenge pont a dél-dunántúli régióban. 


\section{Tercier szektor - turizmus klaszter}

A tercierizációs folyamat keretén belül e klaszternél a gazdasági-üzleti infrastruktúra és szolgáltatás kifejlôdése alkotja az egyik vonalat, a hagyományos fogyasztói-ellátási szolgáltatás pedig az idegenforgalommal kombinálva a másikat. Mivel az idegenforgalom többféle válfaja programozható a Dél-Dunántúl számára, ennek megfelelóen e klaszter is meglehetôsen diverzifikált szervezeti-funkcionális modellt követhet. A kínálatot nyilvánvalóan a differenciált igénystruktúra szerint kell létrehozni. A szervezõdés valószínúleg a lokálisan létrejövô alrendszerek összekötésével és a közösíthetô funkciók egybekapcsolásával mehet végbe. A klaszternek voltaképpen nincs is egységes rendszere.

Elemei tulajdonképpen a legszélesebb kört ölelik fel a lehetséges klasztereket tekintve. Ezek: idegenforgalmi objektumok, kereskedelem-szolgáltatás, kommunikáció, kultúra, mũvészet, környezetvédelem, gazdasági tevékenységek stb.

\section{Feldolgozóipari klaszter}

Az összes lehetséges klasztert tekintve - és ez minôsíti a Dél-Dunántúl iparának fejlettségét (illetôleg fejletlenségét) - ez kívánja a legnagyobb képzelõerôt a stratégia megalkotóitól és majdan a fejlesztésben résztvevốktốl.

A klaszter elemeit a ma pontszerũen meglévô feldolgozóipari bázisok fejlódôképes részei jelenthetik. Ágazati szerkezetét tekintve a paletta rendkívül változatos. A fôbb és a DRI felmérés szerint viszonylag perspektivikus piacú - ágazatok az alábbiak:

- gépipar (világítástechnika, mũszeripar, anyagmozgatási berendezések gyártása),

- üveg- és kerámiaipar (ipari és mũvészeti egyaránt),

- könnyũipar (textil-, konfekció-, kesztyũipar, bôrfeidolgozás),

- kézmüipar.

A klaszter létrejötte praktikusan a régió gazdaságának regionalizálódását jelentené, és egyszersmind azt is, hogy a régió gazdaságszerkezetének szanálása, új alapokra helyezése sinre került.

Hangsúlyozni szeretnénk, hogy minden lehetséges klaszter voltaképpen hipotetikus: egyrészt abban az értelemben, hogy a szervezôdés alapjai állnak csak rendelkezésre, másrészt abban is, hogy a piaci feltételek durva ismerete alapján körvonalazódnak. Mindegyik klaszter egy önálló projektcsomag megalkotását igényli, az érdekelt és lehetséges szereplôk bevonásával, további és alaposabb piacvizsgálattal, jórészt primer információs bázison.

Úgy tũnik, a stratégia megalkotásának egy harmadik fázisát kell ennek során megvalósítani, ahol a fổ kérdés a mikro- és mezo-gazdasági szint összekapcsolása lesz. Nem kizárt, hogy e még mélyebbre hatoló vizsgálat során azután újabb klaszterlehetõségek kerülnek eló, hiszen gondoljunk csak arra, hogy a hagyományok, vagy a humán erôfor- 
rások, sốt bizonyos elképzelések, projektvázlatok például a finomvegyészet, vagy a környezetvédelmi berendezések gyártását is a lehetõségek közé emelhetik, annak ellenére, hogy a közvetlen elôzmények és a szervezeti csírák ma még jórészt hiányoznak.

\section{Irodalom}

Csefkó F. (szerk.) (1994) Tér és közigazgatás. MTA Regionális Kutatások Központja, Magyar Közigazgatási Intézet, Pécs-Budapest.

Horváth Gy. (1992) Crise, politique régionale et PME en Hongrie. Revue Internationale P.M.E. 1. 926. o.

Horváth Gy. - Faragó L. (1992) Systemic change in Hungary and new issues of regional development. In: Steiner, M. - Isak, H. - Marko, J. (szerk.) Alle macht nach unten? Regionen und Gemeinden gestalten die neue Demokratien Europas. Leykam Verlag, Graz, 177-190. o

Horváth Gy. (szerk.) (1993) Régiók és városok az olasz modernizációban. MTA Regionális Kutatások Központja, Pécs.

Hrubi L. (1993) Restructuring in a depressed zone and role of new small enterprises: the case of Baranya county. In: Horváth, Gy. (szerk.) Development strategies in the Alpine-Adriatic region. Centre for Regional Studies of HAS, Pécs, 183-207. o.

Hrubi L. - Horváth Gy. (1992) Restructuring and regional policy in Hungary. Discussion Papers No. 12. Centre for Regional Studies of HAS, Pécs.

Hrubi L. (1993) Az önkormányzatok gazdaságbefolyásoló szerepérôll. (Szerk.: Csefkó F. - Pálné Kovács I.) Tények és vélemények a helyi önkormányzatokról. Pécs, MTA Regionális Kutatások Központja, Pécs, 209-212. o.

Nemes Nagy J. (1993) Regional dimensions of the Hungarian economic transformation. In: Hajdú Z. (szerk.) Hungary: society, state, economy and regional structure in transition. Centre for Regional Studies, Pécs, 245-262. o.

\section{THE ECONOMIC STRUCTURE AND INDUSTRY OF SOUTHERN TRANSDANUBIA}

\section{LÁSZLÓ HRUBI}

There are no uniform, complete measures for the evaluation of the regional economic structure, but some typical tendencies can serve as a standard in connection with the structural change.

Such generally perceptible trends are, for example:

- the modification of the employment structure towards the secondary, and especially the tertiary sectors,

- within industry the progress of the manufacturing sector,

- within industry the weakening of the privileged position of urban settlements,

- the process of the spatial penetration of new organisations. 
The economy of Southern Transdanubia as a whole was not given a more important role in the centrally controlled economic development of the previous period.

Its "average position", the "semi-shade" situation is still typical as it was in the past. Of course, some sectors or smaller regions of the area function as development regions, but these naturally followed not mainly regional but sectoral (or macroeconomic) aspects and interests. Their regional impact, though not insignificant, had only a secondary role. Several areas of the region could often be found in different programmes aimed at the decrease of regional differences.

The lack of long-lasting selected (industrial) development strategies protected the area from suffering the apparent collapses taking place after the change of model: there are only rather regional crisis situations, that can be localised, in the county.

In the breakdown of the active earners by economic sectors, there were moderate changes in the region in 1980-1990. These changes as a whole did not modify the fundamental structural feature that the region - with the exception of Baranya county - is much more agrarian than the whole of the country.

The transition of the economic structure of the Southern Transdanubian region is slow. The transition of the company structure, the adjustment were a bit late, partly because of the inherited, partly because of the present weight, role of the region within the economic potential of Hungary. The appearance of foreign capital is less frequent than the national average, and it affected the smaller units, especially. The change of structure and organisation is the most advanced in the third sector, the dynamics of the transition is slower in industry for the time being, while the selection in agriculture takes place mainly in the counties with less favourable endowments.

As a general element of the modification of the industrial structure, the decline of the importance of light industry and the rising of the importance of food processing should be mentioned, besides the existence of the inherited particularities of the industrial structure. It is mainly urban industry, the network of the village industry, with an exception or two, is still less developed than the not very well advanced national level and shows a quite feeble situation.

The junctions of the regional division of labour and co-operation can be called development clusters that create the basis of the regional development strategy. These clusters are condensation points in the economy of the region that

- on the one hand mean the chain of economic units with sectoral and functional links (a kind of special vertical connection), by the production of a competitive product or service, profitable productive process, mainly relying on and using the resources of the region,

- on the other hand, they mean a connected network of the economic-service units of the region, which can directly transmit the market effects, and also provide the inpoformation flow of common interest and the reaction to market impulses, as well.

Examining the possible clusters the following fundamental bottle-necks can be seen: 
- one is the lack of the first part of the linkage that can be called an innovation system in the narrower sense: both the product- and the technology development are extremely underdeveloped in Southern Transdanubia;

- the other is the basic lack at the end of the linkage , the lack of marketing apparatus, which causes fundamental development problems in two directions, in the organisation of sales and the acquisition of market information.

Analysing the possible main junctions, clusters of the development of the region, a basic particularity is the fact that there is no cluster (and in the foreseeable future there is not going to be) that could be the most particular feature of the economy of the region and could give the regional development a face. Thus the economic development of the region can take place on the basis of a potential with diverse structure.

Industry will not lose importance, although its role in the employment will be less emphasised. Since within industry, food processing is a possible development junction, a great decrease in the role of agriculture cannot be predicted, either. The only new element of the structural modification can be tertialisation.

Translated by Zoltán Raffay 


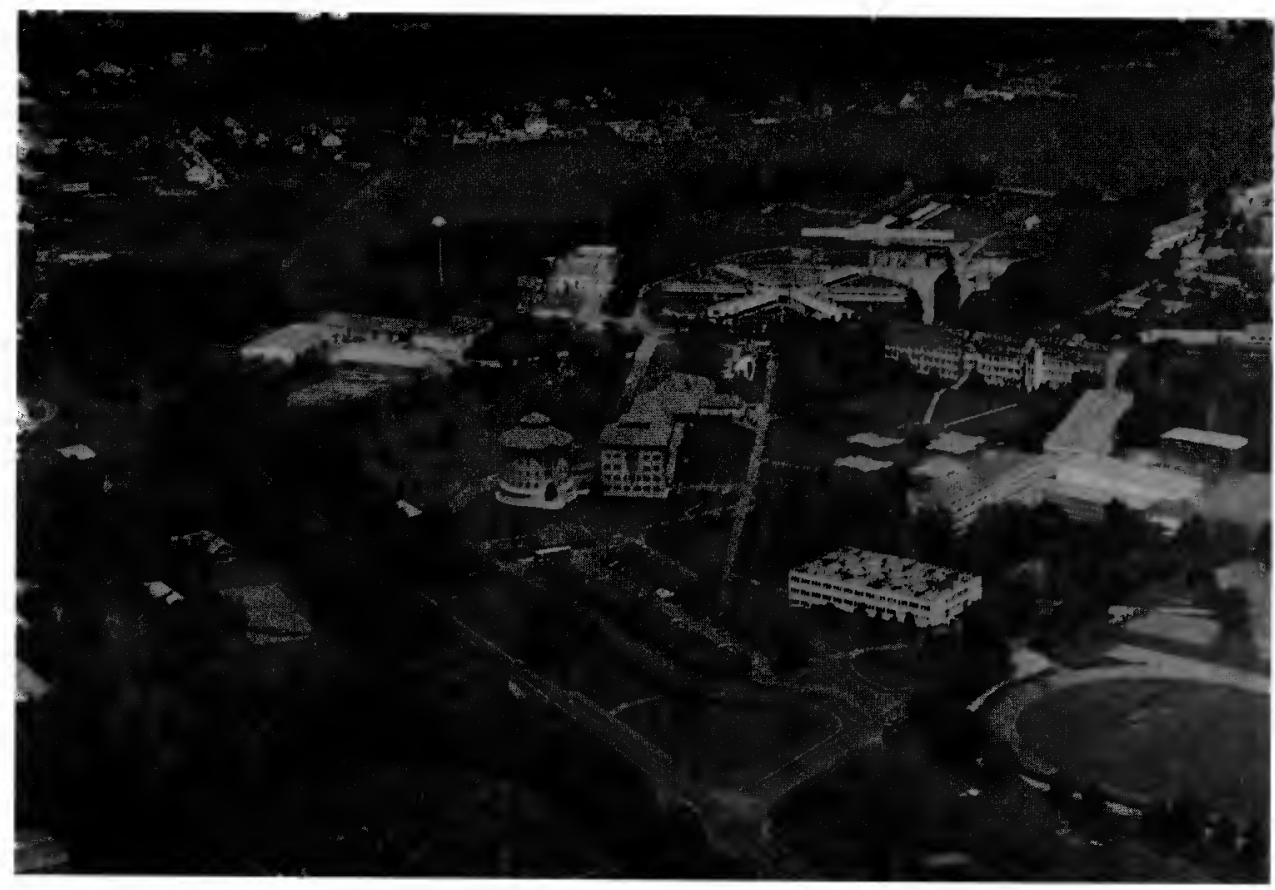

Pannon Agrártudományi Egyetem Állattenyésztési Kara, Kaposvár (Szabados Z.)

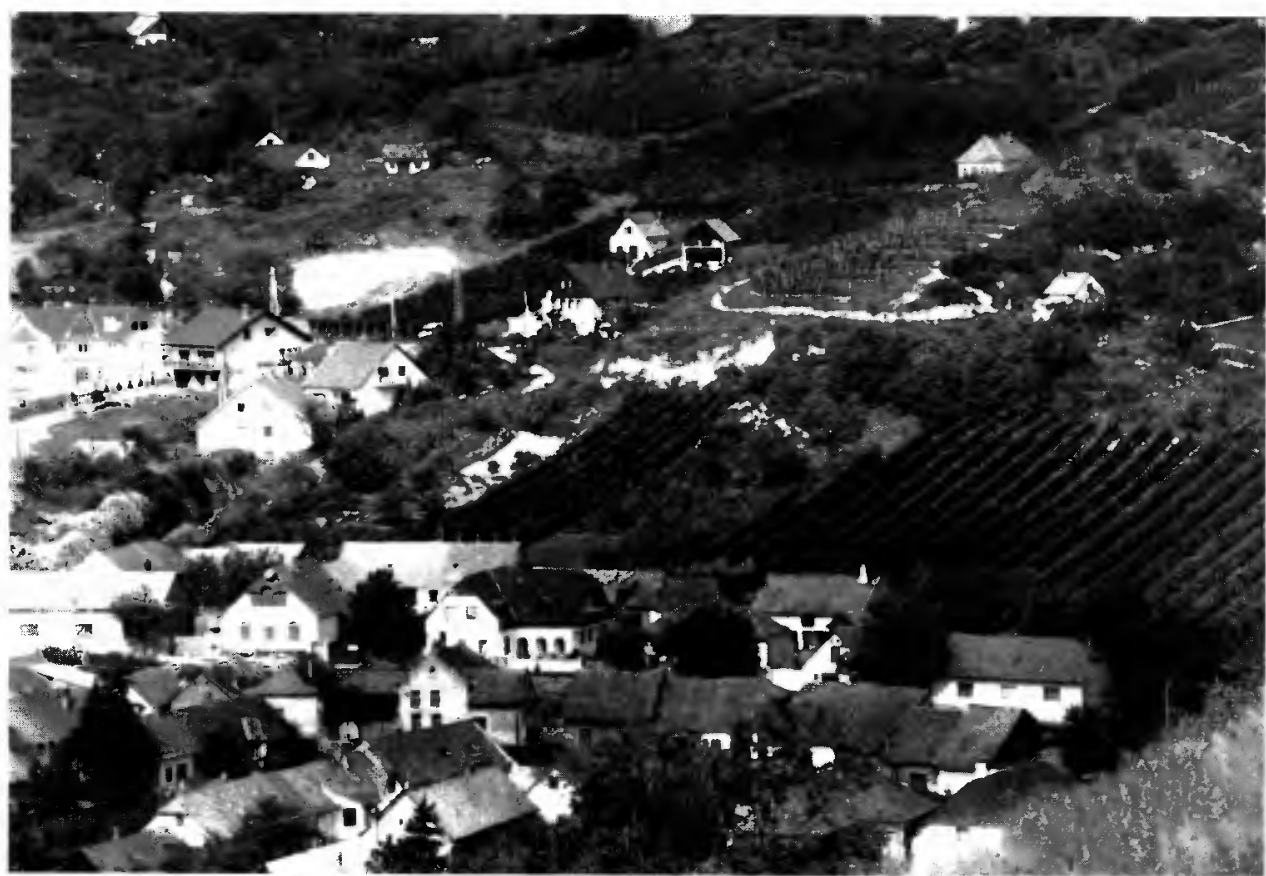

Szekszárd, szôlôhegy (Mánfai Gy.) 